\title{
Portofolio demi Sertifikasi Guru, Harapan atau Impian
}

\author{
Suke Silverius, sukesilver@yahoo.com
}

\begin{abstract}
Abstrak: Guru profesional menjadi dambaan bangsa karena akan menjadi pencipta sumber daya manusia berkualitas demi tersedianya tenaga pembangun berkualitas bagi bangsa Indonesia. Pemerintah mewujudkan dambaan itu melalui program sertifikasi guru yang bertujuan untuk menentukan kelayakan guru sebagai agen pembelajaran, meningkatkan mutu hasil pendidikan dan martabat guru, serta meningkatkan profesionalitas guru dan kesejahteraannya. Untuk mendapatkan sertifikasi itu guru harus memiliki kualifikasi akademik minimum sarjana atau diploma empat dan kompetensi mewujudkan tujuan pendidikan nasional. Demi mendapatkan sertifikasi itu guru harus lulus dalam uji sertifikasi yang dibuktikan dengan berbagai dokumen dalam berkas portofolio. Banyak pihak bersikap skeptis terhadap pelaksanaan sertifikasi karena kuatir terjadinya praktik-praktik KKN demi selembar sertifikat sakti menuju peningkatan kualitas dan pendapatan guru. Tulisan ini menyorotkan berbagai kesulitan dan kendala yang dihadapi guru dalam memenuhi tuntutan portofolio sehingga sertifikasi guru dapat menjadi suatu harapan yang bakal terpenuhi atau sebaliknya merupakan impian semata karena kemustahilan memenuhi tuntutan sertifikasi.
\end{abstract}

Kata kunci: sertifikasi, portofolio, kualitas, dan kesejahteraan

\begin{abstract}
A professional teacher is a yearned-for personnel in terms of creating qualified human resource for the Indonesian development. The government accomplished the yearning by the program of teacher certification that is aimed at specifying teacher appropriateness to become a teaching agent, increasing the quality of education success and teachers status, promote teachers professionalism and prosperity. In order to get a certificate the teacher has to possess academic qualification at least of bachelor or fourth diploma degree and has competency to realize the national education goal. In order to get the certificate the teacher has to pass the certification test as shown by various documents in the set of portfolio. Many people are skeptical towards the certification accomplishment because of the practices of corruption activities for the purpose of obtaining a piece of magical certificate that should be used to get the increase of teacher quality and income. This article is to spotlight numerous difficulties and barriers faced by the teachers in fulfilling the demands of portfolio so that the teacher certificate could become an aspiration that would be accomplished or on the contrary it would be nothing other than a dream because of the impossibility to fulfill the certification demands.
\end{abstract}

Key words: certification, portfolio, quality, and prosperity

\section{Pendahuluan}

Guru profesional dan bermartabat menjadi impian bangsa karena akan melahirkan anak bangsa yang cerdas, kritis, inovatif, demokratis, dan berakhlak. Perwujudan impian ini tidak semudah seperti membalik telapak tangan. Diperlukan kerja keras dan sinergi dari semua pihak, baik pemerintah pusat, pemerintah daerah, masyarakat, maupun guru dan orangtua. Kebijakan pemerintah untuk peningkatan kualitas guru telah digagaskan dengan penetapan kebijakan sertifikasi guru. Sertifikasi guru adalah proses pemberian sertifikat pendidik untuk guru yang telah memenuhi standar kompetensi guru.

Penetapan kebijakan sertifikasi guru mengindikasikan adanya keseriusan dan komitmen yang tinggi pihak pemerintah dalam upaya meningkatkan profesionalisme dan penghargaan kepada guru yang bermuara pada peningkatan kualitas pendidikan nasional.

Sertifikasi guru yang digagaskan dalam rangka meningkatkan kualitas guru demi perbaikan dan penyempurnaan kualitas pembelajaran di sekolah telah dikukuhkan secara yuridis dengan 
diterbitkannya Peraturan Mendiknas Nomor 18, Tahun 2007 tentang Sertifikasi bagi Guru dalam Jabatan. Sertifikasi guru yang sudah mempunyai landasan hukum tersebut dilaksanakan secara bertahap dimulai pada tahun 2007. Adapun pelaksanaan Sertifikasi Guru tersebut merupakan salah satu implementasi dari Undang-Undang Nomor 14, Tahun 2005 tentang Guru dan Dosen.

Dengan pengukuhan yuridis melalui UndangUndang Nomor 20, Tahun 2003 tentang Sistem Pendidikan Nasional, dan Peraturan Mendiknas Nomor 18, Tahun 2007 tentang Sertifikasi bagi Guru dalam Jabatan, serta Peraturan Pemerintah Nomor 19, Tahun 2005 tentang Standar Nasional Pendidikan maka guru berhak dibina untuk menempati status sebagai pendidik profesional. Hak binaan menjadi guru atau pendidik profesional melalui sertifikasi pendidikan diprasyaratkan dengan ketentuan bahwa guru harus memiliki status sebagai pendidik profesional, guru harus memiliki kualifikasi akademik minimum sarjana (S1) atau diploma empat (D4), menguasai kompetensi, memiliki sertifikat pendidik, sehat jasmani dan rohani, serta memiliki kemampuan untuk mewujudkan tujuan pendidikan nasional. Dengan perkataan lain, untuk memenuhi kualifikasi guru sebagai pendidik profesional dituntut kualitas atau mutu yang sepadan sebagaimana dibuktikan oleh sertifikasi yang diperoleh.

Sertifikasi guru bertujuan untuk 1) menentukan kelayakan guru dalam melaksanakan tugas sebagai agen pembelajaran dan mewujudkan tujuan pendidikan nasional, 2) meningkatkan proses dan mutu hasil pendidikan, 3) meningkatkan martabat guru, 4) meningkatkan profesionalitas guru, dan 5) meningkatkan kesejahteraan guru. Peningkatan kesejahteraan guru diberikan kepada guru yang telah lulus uji sertifikasi, baik yang berstatus pegawai negeri sipil (PNS) maupun yang berstatus non-pegawai negeri sipil (swasta) dalam bentuk tunjangan profesi sebesar satu kali gaji pokok.

Demi mendapatkan sertifikasi dengan tujuan luhur itu para guru harus lulus dalam uji sertifikasi yang standar kelulusannya ditetapkan berdasarkan terpenuhi tidaknya, lengkap tidaknya berbagai prasyarat yang dibuktikan dengan berkas dokumen yang diperlihatkan dalam portofolio. Portofolio tidak lain daripada bukti fisik (dokumen) yang menggambarkan pengakuan atas pengalaman profesional guru dalam bentuk penilaian terhadap kumpulan dokumen yang menunjukkan rekaman jejak profesional guru. Dokumen ini terkait dengan unsur pengalaman, karya dan prestasi selama guru yang bersangkutan menjalankan peran sebagai agen pembelajaran. Para guru berharap akan mampu melaksanakan semua persyaratan agar dapat lulus uji sertifikasi guna memperoleh pengakuan sebagai guru profesional. Harapan lain di balik itu ialah penghargaan dan tunjangan profesional yang diberikan karena peningkatan statusnya sebagai pendidik atau guru profosional. Namun, tidak disangka bahwa bukti fisik yang harus disiapkan untuk kelengkapan dokumen portofolio sedemikian susah dan beratnya sehingga terkesan lebih banyak gagalnya daripada berhasil.

Penilaian portofolio mengharuskan semua guru mengumpulkan dokumen yang mendiskripsikan mengenai prestasi mereka, yang terdiri atas 1) kualifikasi akademik; 2) pendidikan dan pelatihan; 3) pengalaman mengajar; 4) perencanaan dan pelaksanaan pembelajaran; 5) penilaian dari atasan dan pengawas; 6) prestasi akademik; 7) karya pengembangan profesi; 8) keikutsertaan dalam forum ilmiah; 9) pengalaman organisasi di bidang pendidikan dan sosial, dan 10) penghargaan yang relevan dengan bidang pendidikan.

Sepuluh komponen portofolio merupakan refleksi dari empat kompetensi guru. Setiap komponen portofolio dapat memberikan gambaran satu atau lebih kompetensi guru peserta sertifikasi, dan secara akumulatif dari sebagian atau keseluruhan komponen portofolio merefleksikan keempat kompetensi guru yang bersangkutan.

Mencermati seluruh uraian di atas, terdapat kekhawatiran akan praktik-praktik jalan pintas atau jalan tol yang diupayakan dengan berbagai cara, halal atau pun tidak halal, demi mendapatkan bukti-bukti fisik portofolio sertifikat guru. Banyak pihak bersikap skeptis dengan dilakukannya sertifikasi tingkat keprofesionalan guru karena kuatir terjadinya sogok-menyogok demi selembar sertifikat yang sakti demi peningkatan pendapatan guru. Jauh-jauh hari para guru mesti sudah siap kecewa terhadap pelaksanaan sertifikasi guru karena pengalaman menunjukkan bahwa di tanah 
air Indonesia sudah demikian parahnya kegiatankegiatan yang sering memperdaya guru. (http:// urip.wordpress.com/2006/10/31/ ada-apadengan-sertifikasi-guru/. Adakah Pertimbangan Penempatan Guru? Pengawas Kurang Awas. Ada Apa dengan Sertifikasi Guru.

Hal-hal tersebut merupakan butir-butir permasalahan yang menuntut jawaban yang bersifat menunjang atau melemahkan kebijakan program sertifikasi pendidikan. Dipertanyakan sikap guru, apakah lebih mengutamakan peningkatan kualitas guru dengan penyaringan tingkat keprofesionalannya, atau lebih mementingkan ditingkatkannya gaji melalui ujian sertifikasi. Kalau yang lebih diutamakan adalah peningkatan kualitas guru maka program sertifikasi memberdaya guru dengan menjadikannya guru profesional. Sebaliknya, kalau yang lebih dipentingkan adalah peningkatan gaji dan mengabaikan upaya peningkatan kualitas guru maka sertifikasi merupakan sarana memperdaya dalam upaya peningkatan kesejahteraan sambil membelakangi profesionalitas guru yang diembannya.

Secara lebih eksplisit, yang menjadi pertanyaan ialah apakah sertifikasi pendidik yang diperoleh seorang guru merupakan jaminan meningkatnya kualitas kompetensi guru? Apakah pelaksana uji sertifikasi bertindak objektif dan jujur? Apakah pelaksanaan sertifikasi mematuhi ketentuan peraturan perundang-undangan demi penegakan hukum? Kebijakan apa yang perlu dianut dan bantuan apa yang patut diberikan agar guru memperoleh kualifikasi tersebut dengan status sebagai pendidik profesional? Apakah calon sertifikasi guru memiliki empat kompetensi yang dituntut yakni kompetensi pedagogik, kepribadian, sosial, dan profesional? Apakah peserta uji sertifikasi telah memenuhi sepuluh komponen portofolio yang merupakan refleksi dari empat kompetensi guru termaksud?

Tulisan ini dimaksudkan untuk menjaring jawaban atas semua pertanyaan dalam permasalahan di atas agar dapat mengungkap kenyataan dan harapan yang terwujud atau yang terabaikan, gairah atau skeptisisme pelaksana dan penerima sertifikat, sehingga dapat mengarah pada simpulan untuk mendukung atau sebaliknya melemahkan sampai pada menghentikan kebijakan program sertifikasi pendidikan. Pertanyaan yang muncul ialah apakah sertifikasi ini menjadi harapan yang bakal terpenuhi bagi guru dalam meningkatkan profesionalitasnya atau sebaliknya merupakan batu sandungan yang sedemikian susahnya untuk dielak sehingga mewujudkan suatu impian nan tak tergapai?

\section{Kajian Teori dan Bahasan}

Tidak dapat dipungkiri bahwa guru adalah ujung tombak dalam pembangunan pendidikan nasional yang bermuara pada pembangunan nasional bangsa. Guru adalah tenaga profesional sebagaimana diamanatkan dalam Pasal 39 ayat 2, UU RI Nomor 20, Tahun 2003 tentang Sistem Pendidikan Nasional, Pasal 2 ayat 1, UU RI Nomor 14, Tahun 2005 tentang Guru dan Dosen, dan Pasal 28 ayat (1) PP RI Nomor 19, Tahun 2005 tentang Standar Nasional Pendidikan. Dalam rangka usaha pembinaan dan peningkatan kemampuan guru sebagai tenaga profesional telah diterbitkan suatu kebijakan pemerintah tentang sertifikasi pendidikan.

Lima butir tujuan sertifikasi guru tersebut pada butir pendahuluan di atas menyiratkan bahwa dari berbagai faktor peningkatan mutu pendidikan, guru memegang peranan penting, di samping fasilitas yang menunjang, kurikulum dan faktor penunjang lainnya. Diakui dan diyakini bahwa sebagus apa pun fasilitas dan kurikulum serta faktor penunjang terkait lainnya yang ada tetapi jika tidak disokong oleh profesionalitas dan kualitas seorang guru maka semua itu menjadi tidak optimal.

Menurut Undang-Undang Nomor 14, Tahun 2005 tentang Guru dan Dosen, sertifikat pendidik diberikan kepada guru yang telah memenuhi persyaratan kualifikasi akademik dan kompetensi sebagai agen pembelajaran serta telah menyelesaikan program pendidikan profesi pendidik dan lulus uji sertifikasi pendidik. Ujian sertifikasi pendidik dimaksudkan sebagai kontrol mutu hasil pendidikan, sehingga para lulusan ujian sertifikasi pendidik diyakini mampu melaksanakan tugas mendidik, mengajar, melatih, membimbing, dan menilai hasil belajar peserta didik.

Yang menjadi pertanyaan ialah apakah sertifikasi pendidik yang diperoleh seorang guru 
merupakan jaminan meningkatnya kualitas kompetensi guru? Perlu kiranya dikaji secara mendalam untuk memberikan jaminan bahwa sertifikasi akan meningkatkan kualitas kompetensi guru. Pertama, sertifikasi merupakan sarana atau instrumen untuk mencapai suatu tujuan, bukan tujuan itu sendiri. Dengan adanya kesadaran dan pemahaman ini guru akan senantiasa meyakinkan dirinya bahwa apa pun yang dilakukan adalah untuk mencapai kualitas. Kalau seorang guru mengikuti kuliah untuk kualifikasi dan berhasil maka ijazah S-1 yang diperolehnya bukan tujuan yang harus dicapai dengan segala cara, termasuk cara yang tidak benar, melainkan konsekuensi dari telah belajar dan telah mendapatkan tambahan ilmu dan ketrampilan baru. Demikian pula dengan hasil uji sertifikasi sebagai bukti bahwa yang bersangkutan telah memiliki kompetensi sebagaimana disyaratkan dalam standard kemampuan guru. Tunjangan profesi adalah konsekuensi logis terhadap kemampuan yang diperolehnya. Dengan demikian, guru mempersiapkan diri dengan belajar yang benar untuk menghadapi uji sertifikasi tanpa upaya dengan jalan lain yang tidak halal guna memperoleh sertifikat profesi itu.

Kedua, tuntutan pelaksana uji sertifikasi. Ada beragam tuntutan dan tantangan dari berbagai sumber, antara lain dalam penentuan lembaga yang berhak melaksanakan uji sertifikasi, keseimbangan geografis, dan pelaksana UndangUndang yang muncul dari kalangan guru sendiri. Lembaga Pendidikan Tenaga Kependidikan (LPTK) Swasta akan menuntut untuk diberi hak menyelenggarakan dan melaksanakan $u j i$ sertifikasi. Berbagai LPTK negeri khususnya di daerah luar Jawa akan menuntut dengan alasan demi keseimbangan geografis. Pelaksana UndangUndang yang sudah senior menuntut berbagai kemudahan agar bisa memperoleh sertifikat profesi tersebut.

Ketiga, penegakan hukum. Dalam pelaksanaan sertifikasi akan timbul beragam peluang untuk praktik-praktik penyimpangan dari aturan main yuridis, antara lain mendapatkan sertifikat profesi dengan jalan pintas, apalagi yang disertai nuansa KKN. Sanksi yang harus dikenakan tanpa pandang bulu ialah mencabut hak melaksanakan sertifikasi dari lembaga yang dimaksud, atau menetapkan seseorang tidak boleh menjadi penguji sertifikasi, dan lain sebagainya. Pemerintah harus konsekuen dan patuh dalam penegakan hukum demi menjaga keutuhan dan kemurnian sertifikasi yang berstandar nasional. Dengan demikian, akan terpenuhi manfaat sertifikasi guru.

Adapun manfaat uji sertifikasi guru di Indonesia ialah a) Melindungi profesi guru dari praktikpraktik yang tidak kompeten, yang dapat merusak citra profesi guru; b) Melindungi masyarakat dari praktik-praktik pendidikan yang tidak berkualitas dan profesional; c) Menjadi wahana penjaminan mutu bagi LPTK, dan kontrol mutu dan jumlah guru bagi pengguna layanan pendidikan; d) Menjaga lembaga penyelenggara pendidikan (LPTK) dari keinginan internal dan tekanan eksternal yang menyimpang dari ketentuanketentuan yang berlaku; e) Memperoleh tunjangan profesi bagi guru yang lulus ujian sertifikasi.

Mekanisme pelaksanaan sertifikasi guru harus sesuai dengan Peraturan Mendiknas Nomor 18, Tahun 2007, sekaligus realisasi dari ketentuan Undang-Undang Nomor 14, Tahun 2005 tentang Guru dan Dosen, yakni penilaian terhadap portofolio.

Penilaian portofolio merupakan pengakuan atas pengalaman profesional guru dalam bentuk penilaian terhadap 10 komponen portofolio. Pertama, kualifikasi akademik yaitu tingkat pendidikan formal yang telah dicapai sampai dengan guru mengikuti sertifikasi, baik pendidikan gelar (S1, S2, atau S3) maupun nongelar (D4 atau Post Graduate Diploma), baik di dalam maupun di luar negeri. Bukti fisik yang dikumpulkan berupa foto kopi ijazah atau sertifikat diploma yang telah dilegalisasi oleh PT yang mengeluarkan atau oleh Ditjen Dikti untuk ijazah/sertfikat luar negeri. Kedua, pendidikan dan pelatihan yaitu pengalaman dalam mengikuti kegiatan pendidikan dan pelatihan dalam rangka pengembangan dan/ atau peningkatan kompetensi dalam melaksanakan tugas sebagai pendidik. Bukti fisik yang dikumpulkan ialah foto kopi sertifikat/piagam/ surat keterangan yang telah dilegalisasi oleh atasan. Ketiga, pengalaman mengajar yaitu masa kerja guru dalam melaksanaan tugas sebagai pendidik pada satuan pendidikan tertentu sesuai dengan surat tugas dari lembaga yang berwenang (dapat dari pemerintah, dan/atau kelompok 
masyarakat penyelenggara pendidikan). Foto kopi Surat Keputusan atau Surat Keterangan yang telah dilegalisasi oleh atasan merupakan bukti fisik yang harus disertakan. Keempat, perencanaan pembelajaran yaitu persiapan mengelola pembelajaran yang akan dilaksanakan dalam kelas pada setiap tatap muka. Perencanaan pembelajaran ini paling tidak memuat perumusan tujuan/kompetensi, pemilihan dan pengorganisasian materi, pemilihan sumber/media pembelajaran, skenario pembelajaran, dan penilaian hasil belajar. Bukti fisik yang dilampirkan adalah dokumen perencanaan pembelajaran (RP/ RPP/SP) yang diketahui/disahkan oleh atasan. Pelaksanaan pembelajaran yaitu kegiatan guru dalam mengelola pembelajaran di kelas. Kegiatan ini mencakup tahapan prapembelajaran (pengecekan kesiapan kelas dan apersepsi), kegiatan inti (penguasaan materi, strategi pembelajaran, pemanfaatan media/sumber belajar, evaluasi, penggunaan bahasa), dan penutup (refleksi, rangkuman, dan tindak lanjut). Bukti fisik yang dilampirkan berupa dokumen hasil penilaian oleh kepala sekolah dan/atau pengawas tentang pelaksanaan pembelajaran yang dikelola oleh guru dengan menggunakan fortmat penilaian yang telah disediakan, dan dilampirkan dalam amplop tertutup. Kelima, penilaian atasan terhadap kompetensi kepribadian dan sosial meliputi aspek-aspek: ketaatan menjalankan ajaran agama, tanggung jawab, kejujuran, kedisiplinan, keteladanan, etos kerja, inovasi dan kreativitas, kemamampuan menerima kritik dan saran, kemampuan berkomunikasi, dan kemampuan bekerja sama dengan menggunakan Format Penilaian Atasan yang telah disediakan. Bukti fisik yang diminta adalah dokumen hasil penilaian dengan menggunakan format penilaian yang telah disediakan, dan dilampirkan dalam amplop tertutup. Keenam, prestasi akademik yaitu prestasi yang dicapai guru, terutama yang terkait dengan bidang keahliannya yang mendapat pengakuan dari lembaga/panitia penyelenggara. Komponen ini meliputi a) lomba dan karya akademik (juara lomba atau penemuan karya monumental di bidang pendidikan atau nonkependidikan) dan b) pembimbingan teman sejawat dan/atau siswa (instruktur, guru inti, tutor, atau pembimbing kegiatan siswa). Bukti fisik yang diminta adalah foto kopi piagam penghargaan/sertifikat, surat keterangan yang telah dilegalisasi oleh atasan. Ketujuh, karya pengembangan profesi yaitu suatu karya yang menunjukkan adanya upaya dan hasil pengembangan profesi yang dilakukan oleh guru, meliputi a) buku yang dipublikasikan; b) artikel yang dimuat dalam media jurnal/majalah/buletin; c) modul/diktat yang minimal mencakup materi pembelajaran selama 1 tahun; d) media/alat pembelajaran dalam bidangnya; e) laporan penelitian tindakan kelas (individu/kelompok); dan f) karya seni (patung, rupa, tari, lukis, sastra, dII). Bukti fisik yang dilampirkan berupa surat keterangan dari pejabat yang berwenang tentang hasil karya tersebut dan dilegalisasi oleh atasan. Kedelapan, keikutsertaan dalam forum ilmiah yaitu partisipasi dalam kegiatan ilmiah yang relevan dengan bidang tugasnya, baik sebagai pemakalah maupun sebagai peserta. Bukti fisik yang dilampirkan adalah foto kopi makalah, piagam/ sertikat yang telah dilegalisasi oleh atasan. Kesembilan, pengalaman organisasi di bidang kependidikan dan sosial yaitu pengalaman guru menjadi pengurus (bukan hanya sebagai anggota) di suatu organisasi kependidikan dan sosial. Pengurus organisasi di bidang kependidikan antara lain pengawas, kepala sekolah, wakil kepala sekolah, ketua jurusan, kepala lab, kepala bengkel, kepala studio, ketua asosiasi guru bidang studi, dan asosiasi profesi. Pengurus organisasi di bidang sosial antara lain menjabat ketua RW, ketua RT, dan ketua LMD. Bukti fisik yang dilampirkan adalah foto kopi surat keputusan/surat keterangan dari pihak yang berwenang yang telah dilegalisasi oleh atasan. Kesepuluh, penghargaan yang relevan dengan bidang pendidikan yaitu penghargaan yang diperoleh karena guru menunjukkan dedikasi yang baik dalam melaksanakan tugas dan memenuhi kriteria kuantitatif (lama waktu, hasil, lokasi/geografis), kualitatif (komitmen, etos kerja), dan relevansi (dalam bidang/rumpun bidang). Bukti fisik yang dilampirkan adalah foto kopi sertifikat/piagam/surat keterangan yang telah dilegalisasi oleh atasan.

(http://74.125.93.132/search?q=cache: ZEHYOVEFXEEJ:www.sertifikasiguru.org/uploads/ File/instrument/sertifikasiguru_dalamjabatan_ 07.pdf+sertifikasi+gurum + portofolio \&cd $=11 \& \mathrm{hl}=$ id\&ct=clnk\&gl=id. Sertifikasi Guru Dalam Jabatan Tahun 2007) 
Portofolio merekam dan mendokumentasi kinerja guru dalam suatu periode. Guru diminta melaporkan bukti fisik komponen portofolio secara lengkap. Bukti fisik tersebut dinilai berdasarkan skor yang telah ditetapkan menurut kategori tertentu. Unsur yang dinilai adalah kompetensi pedagogik, kompetensi kepribadian, kompetensi sosial, dan kompetensi profesional yang diperoleh melalui pendidikan profesi guru sebagaimana yang dimaksud dalam Pasal 8 Undang-Undang Republik Indonesia Nomor 14, Tahun 2005. Secara rinci keempat kompetensi tersebut dapat dideskripsikan sebagai berikut:

Pertama, kompetensi pedagogik adalah kemampuan guru dalam mengelola pembelajaran yang meliputi sekurang-kurangnya (a) pemahaman wawasan atau landasan kependidikan dan teknologi pembelajaran, (b) pemahaman terhadap peserta didik, (c) perancangan pembelajaran dan pelaksanaannya yang bersifat mendidik dan dialogis, (d) evaluasi proses dan hasil belajar, dan (e) pengembangan peserta didik untuk mengaktualisasikan berbagai potensi yang dimilikinya.

Kategori yang dinilai dalam Rencana Pelaksanaan Pembelajaran (RPP) mencakup delapan aspek, yaitu kejelasan perumusan tujuan pembelajaran, pemilihan materi ajar, pengorganisasian materi ajar, pemilihan sumber/media pembelajaran, kejelasan skenario pembelajaran, kerincian skenario pembelajaran, kesesuaian teknik penilaian dengan tujuan pembelajaran, dan kelengkapan instrumen penilaian. Guru diminta melampirkan lima RPP dari semester dan materi yang berbeda yang dianggap terbaik.

Kedua, kompetensi kepribadian ini meliputi sekurang-kurangnya (a) berakhlak mulia, (b) arif dan bijaksana, (c) mantap, (d) berwibawa, (e) stabil, (f) dewasa, (g) jujur, (h) mampu menjadi teladan bagi peserta didik dan masyarakat, (i) mengembangkan diri secara mandiri dan berkelanjutan, dan (j) secara objektif mengevaluasi kinerja sendiri.

Ketiga, kompetensi sosial ini merupakan kemampuan guru sebagai bagian dari masyarakat, sekurang-kurangnya meliputi (a) berkomunikasi lisan, tulisan, dan/atau isyarat, (b) berinteraksi secara efektif dengan peserta didik, sesama pendidik, tenaga kependidikan, pimpinan satuan pendidikan, orang tua/wali peserta didik, dan (c) bergaul secara santun dalam semangat persaudaraan dengan masyarakat sekitar dengan mengindahkan norma serta sistem nilai yang berlaku.

Keempat, kompetensi profesional ini merupakan kemampuan guru dalam menguasai pengetahuan bidang ilmu, teknologi, dan/atau seni yang sekurang-kurang meliputi penguasaan (a) materi pelajaran secara luas dan mendalam sesuai standar isi program satuan pendidikan, mata pelajaran, dan/atau kelompok mata pelajaran yang diampunya, (b) bimbingan bagi peserta didik agar memperoleh kompetensi yang ditetapkan, dan (c) konsep-konsep dan metode disiplin keilmuan, teknologi, atau seni yang relevan dengan program satuan pendidikan, mata pelajaran, dan/atau kelompok mata pelajaran yang diampu.

Hanya dengan mengumpulkan dokumen (bukti fisik) dari kegiatan pengajaran, pendidikan, pelatihan, serta jenis kegiatan sosial dan ilmiah lain yang pernah diikuti oleh guru, seorang guru dapat dinyatakan lulus seleksi.

Yang patut dipertanyakan adalah sejauh mana asesor (tim penilai portofolio) bertindak jujur agar tidak terjebak etika buruk guru karena memalsukan suatu dokumen prestasi atau dokumen kinerja lainnya. Kebijakan Depdiknas tentang sertifikasi guru sangat rawan terhadap terjadinya kolusi dan korupsi (KKN).

Situasi dan peristiwa termaksud di atas menimbulkan kesan pada sebagian guru bahwa program sertifikasi guru yang semula dimaksudkan untuk memberdaya guru ternyata dapat pula sebaliknya berbuntut pada memperdaya guru. Terhadap kesan bahwa sertifikasi guru membuka lahan konspirasi baru di dunia pendidikan guna mem-perdaya-i guru yang selama ini sudah tak berdaya. Sertifikasi merupakan penentu tingkat penghasilan seorang guru maka ia pun akan rela diperdayai oleh oknum-oknum yang terlibat dalam kegiatan pensertifikasian demi naiknya penghasilan bulanannya.

Dipertanyakan pertimbangan mana lebih didahulukan dalam pelaksanaan program sertifikasi, apakah demi peningkatan kualitas guru dengan penyaringan tingkat keprofesionalannya, atau karena akan ditingkatkannya gaji ber- 
dasarkan penyaringan melalui suatu ujian sertifikasi. Kalau alternatif pertama menjadi pilihan maka program sertifikasi memberdaya guru mengantar bangsa Indonesia memasuki hidup sejahtera berkat sumber daya manusia yang dihasilkan oleh pendidikan yang bermutu. Sebaliknya, kalau alternatif kedua yang dipakai maka sertifikasi merupakan sarana memperdaya atau sedikit-dikitnya "sedikit mempersulit" guru dalam upaya peningkatan kesejahteraan sehingga memperlambat kelulusan guru dan pengeluaran negara menjadi tidak boros.

Banyak pihak lain bersikap skeptis dengan dilakukannya sertifikasi tingkat keprofesionalan guru karena kuatir terjadinya praktik-praktik KKN guna mendapatkan selembar sertifikat yang sakti demi peningkatan pendapatan guru. Jauh-jauh hari para guru mesti sudah siap kecewa terhadap pelaksanaan sertifikasi guru karena pengalaman menunjukkan bahwa di tanah air Indonesia sudah demikian parahnya kegiatan-kegiatan yang sering memperdaya guru.

Butir-butir praktik ilegal tersebut di atas sejalan dengan butir-butir kecurangan dalam proses sertifikasi guru sebagaimana diungkap oleh Ketua Tim Independen Sertifikasi Guru, Ahmad Rizali. Ahmad Rizali, kepada SP melalui surat elektroniknya Jumat 14 Maret 2008, mendesak pemerintah agar menghapuskan persyaratan portofolio, khususnya kewajiban memiliki sertifikat dari seminar/lokakarya dalam pelaksanaan sertifikasi guru. Hasil pemantauan di lapangan menunjukkan terjadinya penyimpangan yang sangat besar, yakni sekitar 36 persen dari guru yang mengikuti sertifikasi memalsukan dokumen, termasuk ijazah. Syarat peserta harus sarjana atau strata satu (S1) sulit dipenuhi guru SD di berbagai daerah dan mendorong berbagai Sekolah Tinggi Keguruan dan Ilmu Kependidikan (STKIP) yang belum diakreditasi menawarkan ijazah S1 palsu. Terjadinya pinjam meminjam berbagai sertifikat dari teman sejawat dengan cara di-foto kopi, sementara kepala sekolah menutup mata terhadap kecurangan ini dengan tetap mengesahkan sertifikat palsu tersebut.

Selain memalsukan ijazah, sertifikat seminar/ lokakarya, juga ada indikasi suap. Ahmad Rizali menambahkan, tidak hanya dugaan penyimpangan portofolio, namun ada juga dugaan penyuapan dan pemerasan yang dilakukan oknum dinas atau guru. Karena itu, guru yang dirugikan harus berani melaporkan kepada pihak terkait.

(http://www.suarapembaruan.com/News/2008/ 03/15/Kesra/kes01.htm

Sertifikasi Guru - Evaluasi Persyaratan Portofolio. Ahmad Rizali)

Terhadap praktik-praktik yang bernuansa KKN tersebut di atas harus ada keputusan yang tegas dari guru untuk memilih prinsip memanfaatkan program ini untuk memberdaya diri demi peningkatan profesionalitasnya atau sebaliknya bersikap skeptis atau malah menyerah dengan menggunakan sertifikasi sebagai sarana memperdaya atau sedikit-dikitnya mempersulit diri dalam upaya pembinaan profesionalitas menuju peningkatan kesejahteraan.

Perihal mutu (calon) guru, kenyataan menunjukkan bahwa tidak sedikit calon mahasiswa LPTK merupakan lulusan terbuang yang tidak diterima di perguruan tinggi non-LPTK. Hal ini dikarenakan tidak ada minat masyarakat untuk menyekolahkan anaknya menjadi guru. Namun melalui sertifikasi guru, dengan mutu guru yang semakin meningkat dan kesejahteraan yang semakin tinggi, pamor profesi guru pun ikut membubung di antara profesi lainnya sehingga animo calon guru akan semakin tinggi untuk menjadi seorang guru.

Diyakini, jika semua proses sertifikasi ini berlangsung secara ideal maka tidak mustahil cahaya pembangunan nasional dapat semakin bersinar oleh sumber daya manusia berkualitas dan berdaya saing hasil ciptaan guru, the man behind the gun, yang profesional.

\section{Peningkatan Mutu Pendidikan Dambaan Sertifikasi}

Guru yang adalah "orang di balik senjata" (the man behind the gun) dalam upaya pendidikan di sekolah mengetahui tujuan pembelajaran sebagai sasaran yang hendak dibidik dengan pengajarannya. Dengan adanya tujuan pembelajaran maka para guru dapat menentukan hasil apa yang diinginkan dari para siswanya seusai menerima pengajaran guru.

Dengan mengetahui tujuan itu guru dapat mengarahkan laras senjatanya yakni metode 
belajar-mengajar yang hendak diterapkannya agar supaya bahan ajarnya dapat diterima dan dikuasai dengan baik oleh para siswa. Sejauh mana kecermatan bidikannya guru harus mampu membuat alat evaluasi pengajaran yang baik. Untuk dapat menciptakan alat evaluasi yang baik guru harus menguasai berbagai kaidah penulisan soal, baik untuk soal-soal uraian maupun untuk soal-soal non-uraian (pilihan ganda dan lain-lain).

Hasil evaluasi mengungkapkan jumlah lulusan terus bertambah dari tahun ke tahun meskipun mutu pendidikan masih memprihatinkan. Mutu pendidikan di Indonesia belum memadai untuk mampu menjawab tantangan pengadaan sumber daya manusia dan masyarakat Indonesia yang berkualitas. Tantangan ini sedemikian mendesaknya karena justru menjadi prasyarat untuk peningkatan pembangunan nasional Indonesia. Beberapa terobosan yang telah dilancarkan dalam rangka upaya peningkatan mutu pendidikan ialah penciutan kurikulum, penerapan kebijakan relevansi pendidikan, metode belajar-mengajar, dan mutu guru serta program sertifikasi guru.

Tidak dapat dipungkiri bahwa kendatipun tingkat kuantitas dan kualitas guru sudah cukup memadai belumlah menjadi jaminan keberhasilan upaya peningkatan mutu pendidikan selama kesejahteraan guru belum memadai. Bagaimana mungkin guru bisa menjalankan tugasnya dengan tenang dan nyaman kalau masih harus terus memikirkan nasib kesejahteraan keluarganya yang tidak lepas-lepas dari keterpurukan?

Peningkatan mutu guru dan mutu pendidikan hanya dapat dimungkinkan apabila kesejahteraan guru terjamin memadai. Mengingat penghasilan guru di Indonesia pada umumnya relatif rendah maka sangat diharapkan pemenuhan janji tambahan penghasilan menurut ketentuan Pasal 14 ayat (1) Undang-Undang Nomor 14, Tahun 2005 tentang Guru dan Dosen pada 30 Desember 2005 dapat terlaksana tanpa tawar menawar. Untuk mendapatkan tambahan penghasilan yang menimbulkan decak kaget dan kagum itu dituntut berbagai persyaratan dari para guru. Dalam pasal 16, misalnya, ditetapkan bahwa (1) Pemerintah memberikan tunjangan profesi sebagaimana dimaksud dalam Pasal 15 ayat (1) kepada guru yang telah memiliki sertifikat pendidik yang diangkat oleh penyelenggara pendidikan dan/atau satuan pendidikan yang diselenggarakan oleh masyarakat; (2) Tunjangan profesi sebagaimana dimaksud pada ayat (1) diberikan setara dengan 1 (satu) kali gaji pokok guru yang diangkat oleh satuan pendidikan yang diselenggarakan oleh pemerintah atau pemerintah daerah pada tingkat, masa kerja, dan kualifikasi yang sama.

Kemudahan yang diterapkan dalam pelaksanaan peraturan perundangan itu bagaimana pun juga harus dapat terlaksana tanpa dipersulit dengan berbagai cara dan alasan, baik oleh pembuat kebijakan dan peraturan turunannya maupun oleh asesor ujian sertifikasi. Diperoleh informasi yang meragukan kejujuran dan kemurnian asesor ujian sertifikasi dalam melaksanakan tugasnya. Dengan sikap yang tidak terpuji itu, guru yang belum memiliki sertifikat pendidik jangan bermimpi untuk mendapatkan tunjangan profesi yang setara dengan 1 (satu) kali gaji pokok. Keraguan ini berdampak pada kebijakan peningkatan mutu pendidikan.

Persoalannya sekarang dan di waktu mendatang ialah seandainya sudah banyak guru yang memiliki sertifikat profesi, apakah ada jaminan terjadinya peningkatan mutu pendidikan? Di sinilah kontradiksi antara profesionalitas guru dan kesejahteraannya. Peningkatan kualifikasi akademik dan sertifikasi guru bukan menjadi jaminan kinerja guru akan menjadi lebih baik. Silverius (2005) mengungkapkan parahnya komersialisasi di sekolah yang sudah mencapai titik yang sangat memprihatinkan. Komersialisasi dalam bentuk pungutan liar (pungli) terjadi mulai dari saat penerimaan siswa baru yang jadi ajang 'menimba uang', sampai proses belajar mengajar. Siswa dijadikan sasaran empuk pemerasan antara lain dengan diharuskan membeli buku paket atau lembar kerja siswa (LKS) tertentu di sekolah, diharuskan membeli pakaian seragam dari sekolah dengan harga yang melambung tinggi.

Kebijakan sekolah itu dikaitkan pula dengan kesejahteraan guru yang sangat memprihatinkan, sehingga harus 'ngobyek' demi memenuhi kebutuhan keluarganya. Jika situasi ini tidak dapat dihindari maka siswa akan dikorbankan dan mutu pendidikan ditelantarkan. Bagaimana mungkin guru berdedikasi dalam edukasi kalau penghasilannya senantiasa mengalami reduksi dengan berbagai macam pemotongan? Padahal tanpa 
kesungguhan guru berdedikasi dalam edukasi maka mutu pendidikan tidak mungkin akan beringsut meningkat. Jadi, kalau benar-benar berkeinginan untuk meningkatkan mutu pendidikan maka conditio sine qua non di balik itu ialah meningkatkan taraf kesejahteraan guru.

Silverius (2004) menulis bahwa pelaksanaan perdagangan buku oleh kepala sekolah dan guru yang diharuskan pembeliannya kepada para (orangtua) siswa membawa dampak yang tidak sehat bagi para siswa. Para siswa melihat sendiri bagaimana upaya para tenaga kependidikan itu untuk mensejahterakan diri tanpa menghargai kaidah atau prinsip didaktik dan moral.

Guru ikut dalam kegiatan ini karena kesejahteraan diri dan keluarganya belum terpenuhi secara memadai. Oleh sebab itu, di samping melaksanakan kegiatan lain di luar sekolah seperti ngojek, ngamen, jualan, dan lain sebagainya, guru juga terlibat langsung dalam perdagangan buku-buku pelajaran. Selama kesejahteraan guru belum mendapat perbaikan semestinya dari pihak terkait maka praktik-praktik yang dinilai tak terpuji ini pada akhirnya harus dinilai sebagai praktik yang "terpuji" demi kehidupan diri dan keluarga guru. Siswa yang melihat dan mengalami secara langsung seluruh peristiwa ini menanam semangat itu dalam dirinya dan tidak mustahil akan dilaksanakan juga dalam hidupnya kendatipun dalam wujud yang berbeda. Asal demi kesejahteraan diri dan keluarga, cara dan jalan apa pun patut dipikirkan dan dilaksanakan. The end justifies the mean. Tujuan menghalalkan cara.

Pekerjaan rumah yang tak kalah besar dalam menyikapi kebijakan sertifikasi guru ialah mendidik calon guru demi menciptakan generasi guru baru yang intelek, transformatif dan profesional. Hal ini tentu menjadi tantangan bagi lembaga pendidikan tenaga kependidikan (LPTK). Mau tidak mau, perlu dikaji terlebih dahulu lembaga yang selama ini menghasilkan tenaga guru. Sejauh manakah profesi guru untuk pantas disebut guru profesional? Sejauh mana gelar honoris (kehormatan) «guru » tidak dikualifikasikan sebagai gelar humoris yang berasal dari pelecehan hasil kualifikasi peserta didik buangan?

Dengan diberlakukannya ketentuan sertifikasi, pelecehan terhadap profesi guru dapat terkikis menghilang. Sertifikasi, yang salah satu tujuannya adalah meningkatkan kesejahteraan guru, merupakan cara terbaik untuk menepis anggapan umum bahwa guru adalah profesi "buangan," yang terpaksa dijalani ketika seseorang tidak bisa menemukan pekerjaan lain yang "lebih baik". Profesi buangan itu diakibatkan oleh tuntutan memperoleh dan meningkatkan kesejahteraan sehingga daripada tidak mendapat pekerjaan, menjadi guru saja pun syukur Alhamdulillah.

Silverius (2005) mengatakan bahwa rendahnya kesejahteraan para pendidik menjadi salah satu penyebab terpuruknya pendidikan di Indonesia. Saat ini cukup sulit menemukan generasi muda yang bercita-cita menjadi guru karena anggapan yang tercipta adalah "Hidup Guru itu Susah". Tidak mengherankan adanya kenyataan yang mengungkap kurangnya jumlah guru di tanah air.

Statistik Pendidikan tahun 2007/2008 untuk tingkat Taman Kanak-Kanak (PSP Balitbang Depdiknas. Sedang naik cetak) menunjukkan jumlah guru dan kepala sekolah yang PNS sebanyak 43,225 orang dengan rincian: golongan II sebanyak 6,706 orang, golongan III sebanyak 30,741 orang dan golongan IV sebanyak 5,778 orang. Jumlah guru dan kepala sekolah yang PS sebanyak 190,338 orang dengan rincian: guru tetap yayasan sebanyak 6,706 orang, guru bantu pusat sebanyak 13,064 orang guru bantu daerah sebanyak 6,576 orang dan guru tidak tetap sebanyak 59,159 orang. Total keseluruhan sebanyak 233,563 orang. Rasio guru (termasuk kepala sekolah) per sekolah sebanyak 4 orang, sejak tahun 2004/2005 sampai dengan 2007/ 2008. Rasio kelas per guru (termasuk kepala sekolah) dari tahun 2004/2005 sebesar 0,60, tahun 2005/06 sebesar 0,58, tahun 2006/07 sebesar 0,57 dan tahun 2007/08 sebesar 0,59.

Statistik Pendidikan juga mengungkapkan banyaknya tenaga guru yang menjadi pegawai kantor sehingga tidak mengajar di sekolah. Hal ini turut menjadi penyebab timbulnya keluhan kekurangan guru, baik guru kelas maupun guru bidang studi. Kenyataan juga mengindikasikan rendahnya mutu atau kualitas para guru di sekolah dan perguruan tinggi.

Silverius (2003) menyimpulkan bahwa keluhan mengenai kurangnya jumlah dan kualitas 
guru mengindikasikan masih rendahnya ketersediaan guru, baik secara kuantitatif maupun kualitatif. Situasi ini masih diperparah oleh rendahnya kesesuaian latar belakang pendidikan guru dengan bidang studi yang diajarkan."

Pada tulisan lain berjudul "Quo Vadis" Pendayagunaan Guru, Silverius mengatakan bahwa aspek kualitas berkaitan dengan latar belakang pendidikan dan kesesuaian latar belakang pendidikan dengan bidang studi yang diajarkannya. Untuk mengetahui situasi itu diperlukan suatu pemetaan. Dengan pemetaan itu dapat diketahui jumlah guru yang memiliki dan tidak memiliki latar belakang pendidikan yang sesuai untuk mengajar pada jenjang Sekolah Lanjutan (SLTP, SMU, SMK) dan sekaligus mendeteksi kesesuaian dan ketidaksesuaian bidang studi yang diajarkannya dengan latar belakang pendidikannya itu. Ketidaksesuaian termaksud dapat dipredikatkan "korupsi".

Logika yang mendasari pemberian predikat "korupsi" terhadap ketidaksesuaian guru ialah bahwa seorang guru harus mengajarkan materi pembelajaran yang baik dan benar sesuai spesialisasi kemampuannya. Untuk jerih payah dan usahanya ini dia pantas menerima pembayaran penghasilan menurut ketentuan perundangan yang berlaku. Dengan demikian, guru matematika, misalnya, harus mengajarkan matematika yang merupakan spesialisasi kemampuannya. Kalau guru matematika dipercayakan untuk mengajar Bahasa Indonesia maka dia menyajikan materi pembelajaran yang tidak sesuai dengan spesialisasi kemampuannya itu. Sering orang berucap sinis, guru itu pintar duluan "satu malam". Guru baru mempersiapkan diri dengan belajar terlebih dahulu materi pembelajaran yang akan diajarkan keesokan harinya kepada anak didiknya. Di sinilah, guru itu mengajar mata pelajaran yang tidak sesuai spesialisasinya namun dibayar sebagai seorang "spesialis mata pelajaran" tersebut. Sudah mengajar sedikit (apalagi kalau ada yang salah) namun dibayar mahal. Di sinilah masuknya nilai "korupsi".

Peluang menjadi guru merupakan suatu cara lain untuk memperoleh pendapatan demi kesejahteraan bagi diri dan keluarga. Usaha yang dilakukan ialah melamar ke mana-mana. Andaikata mengalami kesulitan direkrut menjadi guru di salah satu sekolah yang ingin dimasukinya maka guru melihat terbuka tidaknya peluang untuk menggunakan senjata pamungkas "sogok". Calon guru rela menyisihkan penghasilannya bahkan bila perlu dengan jalan meminjam sekalipun, demi memberikan "upeti" pelicin kepada pihak-pihak yang merupakan pengambil kebijakan penerimaan tenaga guru di sekolah. Finis coronat opus. Tujuan memahkotai cara.

Semua bentuk korupsi yang dirangkai dalam paparan di atas dapat dijadikan pengalaman untuk pelaksanaan korupsi di tempat kerja setelah lulus dari bangku sekolah. Melalui pengalaman di sekolah yang dimarakkan dengan berbagai cara dan bentuk korupsi itu, suara batin dan sikap lulusan telah terbentuk untuk melanggengkan budaya korupsi sampai ke luar lingkup sekolah yakni di tempatnya bekerja. Di sinilah letaknya "korupsi via sekolah". Apabila hal ini terlaksana dalam kaitan dengan pembangunan bangsa, maka semakin suburlah lahan-lahan KKN dan semakin parahlah kesejahteraan rakyat sampai menjadi impian yang tak kesampaian.

Harus disadari, kondisi guru seperti yang tercermin saat ini, merupakan keprihatinan bersama. Kondisi ini yang harus dihadapi, bukan menjadi ajang untuk menyangkal atau malah menyalahkan pihak tertentu. Dari itu semua, yang paling berkepentingan adalah pribadi guru sendiri. Namun, hal itu jangan sampai untuk mematahkan semangat rekan guru yang masih ingin menghidupi keguruannya. Diperlukan suatu gebrakan banting stir untuk mengembalikan citra dan menghidupkan profesionalisme guru.

Terdapat bermacam-macam pertanyaan yang memerlukan kajian dalam hal pemahaman dan penerapan sertifikasi pendidikan. Siapa yang memberikan sertifikasi? Apakah sang pemberi sertifikasi ini disertifikasi juga? Oleh siapa? Jika ditelusuri lebih dalam, yang memberi sertifikasi adalah asesor dan LPTK. Penilaian portofolio dan ujian diberikan oleh asesor. Tanpa mengurangi penghargaan terhadap objektivitas penilaiannya, dikhawatirkan terbukanya peluang praktik KKN pada proses ini.

Pertanyaan selanjutnya, jika seorang guru atau dosen tidak memiliki sertifikasi apakah dia tidak boleh mengajar? Guru atau dosen sudah diberi ilmu yang akan menjadi materi ujian 
sertifikasi maka pertanyaannya ialah apakah masih harus diuji lagi sebelum diberikan sertifikasi? Apakah dengan hanya memberikan ujian tanpa peningkatan mutu guru berakibat kualitas siswa akan naik? Saat ini, sekolah masih kekurangan guru maka pertanyaannya ialah kalau nanti digunakan sistem sertifikasi dan banyak yang tidak bisa mendapatkan sertifikat, apakah kelas dibiarkan semakin kosong? Pertanyaanpertanyaan ini menjadi PR bersama. Jawaban atas pertanyaan itu membimbing dan menggiring ke arah upaya peningkatan profesionalitas guru yang akan berujung pada peningkatan pamor profesi guru.

\section{Kolusi Sertifikasi Menjalin Korupsi}

Ahmadin menyebutkan beberapa ketentuan yang rentan melahirkan masalah dalam proses sertifikasi guru (http://www.fajar.co.id/news.php? newsid=41205. 24 Sep 2007). Pertama, sebelum penilaian dilakukan oleh tim asesor, terlebih dahulu dilakukan seleksi internal pada dinas pendidikan masing-masing kabupaten/kota. Masalah pada proses seleksi ini yang menyangkut masa kerja dan usia berpeluang melahirkan "permainan" dengan mendahulukan guru yang lebih tua (senior) dan memiliki masa kerja yang lama. Kedua, adanya persyaratan mengenai kualifikasi akademik untuk ikut serta dalam proses seleksi sertifikasi membuka peluang praktik jual-beli ijazah yang sulit dihindari sehingga terjadi pengabaian hakikat pendidikan sebagai proses. Ketiga, prasyarat untuk memperoleh sertifikat atau piagam sebagai bukti fisik untuk penilaian mendorong guru untuk aktif mengikuti secara instan berbagai kegiatan ilmiah baik seminar, lokakarya, diklat, dan kegiatan ilmiah lainnya kendatipun cara ini memberi peluang untuk korupsi melalui suap dan sogok. Keempat, komponen penilaian sertifikasi yang berhubungan dengan proses pengajaran oleh guru di sekolah berpeluang menimbulkan persekongkolan antara kepala sekolah, pengawas, dan guru itu sendiri untuk memberikan penilaian sangat tinggi padahal kenyataannya tidak setinggi itu. Kelima, partisipasi dalam kegiatan-kegiatan sosial di masyarakat yang dituntut dari guru sebagai aspek pendukung profesionalitas seorang guru dapat dipastikan menuai masalah yaitu praktik atau tindak pemberian surat keterangan fiktif. Keenam, komponen penilaian berupa karya ilmiah melahirkan kecenderungan memperoleh karya dari orang lain dengan berbagai cara dan bentuk komersialisasi.

Aneka modus tidak wajar tersebut di atas justru tidak melahirkan tenaga pengajar profesional dalam kategori yang sesungguhnya. Ada semacam tindakan diskriminatif bahkan yang bersifat kolutif dalam proses seleksi peserta sertifikasi, sehingga ada guru yang pesimis dan kuatir tidak dapat kesempatan untuk ikut serta dalam proses sertifikasi (ahm4d1n_unm@yahoo. co.id).

Walau dianggap sebagai langkah maju, mekanisme program sertifikasi yang diatur dalam Peraturan Menteri Pendidikan Nasional Nomor 18/ 2007 belum banyak membantu guru. Mekanismenya masih tetap rumit dan pelik. Selain itu, peluang terjadinya praktik korupsi yang dilakukan penyelenggara sertifikasi pun sangat terbuka sehingga akan menambah masalah bagi guru yang ingin secara murni memperoleh sertifikasi guru. (http://www.antikorupsi.org/mod.php?

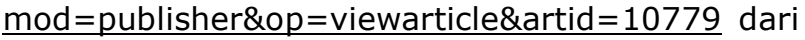
Jawa Pos, 4 Juli 2007).

\section{Animo Guru Terhadap Sertifikasi}

Guru senantiasa dituntut menjadi orang berkemampuan baik, menjadi guru profesional. Di satu sisi guru dituntut harus mencurahkan segala potensi profesionalnya untuk mendidik, di sisi lain kehidupan keluarga menuntut upaya keras untuk mendapat tambahan penghasilan demi memenuhi kebutuhan dasar agar dapur tetap berasap. Kenyataan yang dihadapi menunjukkan bahwa bisa hidup sudah sebuah keajaiban. Situasi ini memustahilkan peluang guru mengembangkan diri, entah dengan cara berlangganan koran, membeli buku, majalah, jurnal, atau bersilancar di internet mencerna informasi baru. Pengembangan diri guru menghadapi masalah bila terkendala dengan ketersediaan sarana dan prasarana yang belum memadai.

Betapa pun reyotnya gedung sekolah dan ruang-ruang kelasnya, betapa pun minimnya sarana dan prasarana, betapa pun fasilitas pendidikan yang (sangat) memprihatinkan, guru 
senantiasa dituding sebagai penyebab rendahnya kualitas pendidikan. Guru yang berfungsi sebagai "the man behind the (unloaded) gun" dihimbau 'bertempur' menunaikan tugas mulia bangsa bersalempangkan salendang "Pahlawan Tanpa Tanda Jasa" tanpa dibekali 'senjata' memadai.

Rendahnya animo guru terhadap sertifikasi pendidikan dapat dibaca dari data tingkat kelulusan sertifikasi guru. Dari 860 guru SD dan SMP peserta sertifikasi di wilayah Surakarta, hanya 8,25 persen atau 71 orang yang lolos. Sementara 61,67 persen (531 orang) diharuskan melengkapi dan 27,76 persen atau 239 orang masuk kategori harus mengikuti diklat profesi guru.

Di Medan, sertifikasi tampaknya kurang diminati. Apa pun alasannya, sampai batas akhir pendaftaran Senin 24/9/2007, Dinas Pendidikan Kota Medan tidak mengirimkan seorang pun dari kuota 205 guru untuk disertifikasi. Hanya 14 dari 25 kabupaten/kota di Sumut mengirimkan guru untuk disertifikasi. (Http://Www.SuarakaryaOnline.Com/News. Html? Id =183363)

Untuk peningatan kualitas guru, pemerintah harus menganggarkan pendanaan yang cukup besar untuk melakukan program-program seperti workshop dan seminar untuk menambah profesionalitas guru. Berarti akan terjadi pengeluaran yang dikuatirkan akan sia-sia apabila pelaksanaan sertifikasi guru tidak terlaksana menurut ketentuan yang telah digariskan. Dikuatirkan sertifikasi guru akan dicemari tangantangan kotor koruptor dalam berbagai cara dan wujudnya. Begitu ada praktik kolusi dan korupsi (KKN) maka sertifikasi akan gagal sehingga tujuan luhur peningkatan mutu akan tinggal impian nan hampa tak terwujud. Dikuatirkan pula akan terjadi kecemburuan, pertikaian dan permusuhan antara guru yang sudah memperoleh sertifikasi dengan remunerasi peningkatan gaji sebesar satu kali gaji pokok dengan guru yang belum sempat menikmati peningkatan kesejahteraan tersebut.

Pidato Pengantar Keterangan Pemerintah atas Rancangan Anggaran Pendapatan dan Belanja Negara Tahun 2010 beserta Nota Keuangannya pada Rapat Paripurna Luar Biasa DPR, Senin 3 Agustus 2009, presiden Susilo Bambang Yudhoyono memberikan angin segar bagi para guru dan dosen. Alokasi tunjangan profesi guru dari dana alokasi umum (DAU) direalokasikan sebesar Rp 8,9 triliun sementara tambahan tunjangan kependidikan bagi guru sebesar Rp 7,9 triliun. Sebagaimana sudah diterapkan sejak tahun 2006, guru yang sudah lulus sertifikasi akan mendapat tambahan penghasilan satu kali gaji pokok dan bagi guru yang mau bertugas di daerah terpencil akan mendapat pula tambahan penghasilan sebesar satu kali gaji pokok. Jadi, guru bersertifikasi yang bekerja di daerah terpencil akan mendapat tambahan penghasilan sebesar dua kali gaji pokok (Kompas, 4 Agustus 2009).

Penerapan kebijakan ini tetap memerlukan pengkajian yang sangat cermat agar dapat terlaksana dengan murni dan berkeadilan tanpa dihinggapi praktik-praktik yang mencemarkan citra kependidikan di tanah air. Apabila terjadi pencemaran citra kependidikan, terutama yang berkaitan dengan sertifikasi - hal itu tidak diinginkan - maka kebijakan sertifikasi perlu dikaji secara lebih tuntas untuk menemukan titik terangnya menuju perubahan dan perbaikannya, atau bila mengalami jalan buntu maka dengan legowo bisa sampai pada keputusan bahwa kebijakan dan program sertifikasi ini dihapus sama sekali.

\section{Simpulan dan Saran}

\section{Simpulan}

Sebagai ujung tombak dalam pembangunan pendidikan nasional yang bermuara pada pembangunan nasional bangsa, guru adalah tenaga professional. Dalam rangka usaha pembinaan dan peningkatan kompetensi guru sebagai tenaga profesional telah diterbitkan suatu kebijakan pemerintah tentang sertifikasi pendidikan. Pemerhati pendidikan dihadapkan pada pertanyaan apakah kebijakan sertifikasi pendidik terhadap seorang guru merupakan jaminan meningkatnya kualitas kompetensi guru? Hal ini memerlukan suatu kajian mendalam dengan memperhatikan sertifikasi sebagai sarana mencapai suatu tujuan, bukan tujuan itu sendiri, dan tuntutan pelaksana uji sertifikasi serta penegakan hukum.

Uji sertifikasi dimaksudkan untuk melindungi profesi guru dari praktik-praktik yang tidak 
kompeten, yang dapat merusak citra profesi guru, melindungi masyarakat dari praktik-praktik pendidikan yang tidak berkualitas dan profesional, menjadi wahana penjaminan mutu bagi LPTK, menjaga LPTK dari keinginan yang menyimpang dari ketentuan-ketentuan yang berlaku, dan memperoleh tunjangan profesi bagi guru yang lulus ujian sertifikasi. Demi mendapatkan sertifikasi guru harus lulus dalam uji sertifikasi yang dibuktikan dengan berbagai dokumen dalam berkas portofolio.

Portofolio merupakan pengakuan atas pengalaman profesional guru dalam bentuk penilaian terhadap 10 komponen portofolio yakni kualifikasi akademik, pendidikan dan pelatihan, pengalaman mengajar, perencanaan pembelajaran, penilaian atasan terhadap kompetensi kepribadian dan social, prestasi akademik, karya pengembangan profesi, keikutsertaan dalam forum ilmiah, pengalaman organisasi di bidang kependidikan dan social, dan penghargaan yang relevan dengan bidang pendidikan.

Portofolio sebagai rekaman dokumen kinerja guru dalam suatu periode merupakan bukti fisik dari kegiatan pengajaran, pendidikan, pelatihan, serta jenis kegiatan sosial dan ilmiah lain yang pernah diikuti oleh guru, terhadap kompetensi pedagogik, kepribadian, sosial, dan profesional .

Perangkat bukti fisik dinilai oleh asesor maka komitmen asesor sangat dituntut untuk bertindak jujur agar tidak terjebak etika buruk guru karena memalsukan suatu dokumen prestasi atau dokumen kinerja lainnya. Situasi ini sangat rawan terhadap terjadinya kolusi dan korupsi (KKN). Timbul kesan bahwa program sertifikasi guru yang semula dimaksudkan untuk memberdaya guru ternyata dapat pula sebaliknya berbuntut pada memperdaya guru. Mana yang lebih diutamakan dalam pelaksanaan program sertifikasi, apakah peningkatan kualitas guru berdasarkan penyaringan tingkat keprofesionalannya, atau peningkatan gaji berdasarkan penyaringan melalui suatu ujian sertifikasi. Hal ini bertalian erat dengan masa depan pembangunan nasional.

Jika semua proses sertifikasi berlangsung secara ideal maka tidak mustahil keberhasilan pembangunan nasional semakin meningkat oleh sumber daya manusia berkualitas dan berdaya saing hasil ciptaan guru, the man behind the gun, yang profesional. Kendatipun demikian, peningkatan kualifikasi akademik dan sertifikasi guru bukan menjadi jaminan kinerja guru akan menjadi lebih baik.

Persoalan kini dan di waktu mendatang ialah seandainya banyak guru memiliki sertifikat profesi, apakah ada jaminan terjadinya peningkatan mutu pendidikan? Di sinilah kontradiksi antara profesionalitas guru dan kesejahteraannya dalam penerapan sertifikasi guru.

Kajian dalam hal pemahaman dan penerapan sertifikasi guru memunculkan beragam pertanyaan. Siapa yang memberikan sertifikasi? Apakah sang pemberi sertifikasi dikenakan sertifikasi juga? Oleh siapa? Sebagaimana diketahui, pemberi sertifikasi adalah asesor dan LPTK yang juga bertugas menilai portofolio dan ujian. Tanpa mengurangi penghargaan terhadap objektivitas penilaiannya, dikhawatirkan terbukanya peluang praktik KKN pada proses ini.

Guru atau dosen sudah dibekali ilmu yang akan menjadi materi ujian sertifikasi . Timbul pertanyaan, jika seorang guru atau dosen tidak memiliki sertifikasi apakah dia tidak boleh mengajar? Apabila guru atau dosen hanya boleh mengajar jika sudah memiliki sertifikasi, apakah guru atau dosen tersebut masih harus diuji lagi sebelum diberikan sertifikasi? Apakah dengan hanya memberikan ujian tanpa peningkatan mutu guru berakibat kualitas siswa akan naik? Dewasa ini, masih banyak sekolah kekurangan guru maka pertanyaannya ialah kalau nanti digunakan sistem sertifikasi dan banyak yang tidak bisa mendapatkan sertifikat, apakah kelas dibiarkan kosong? Jawaban atas pertanyaan-pertanyaan di atas menggiring ke arah upaya peningkatan profesionalitas guru yang akan berujung pada peningkatan pamor profesi guru.

Ada beberapa ketentuan yang rentan melahirkan masalah dalam proses sertifikasi guru. Pertama, seleksi internal pada dinas pendidikan masing-masing kabupaten/kota sebelum penilaian oleh asesor memberi peluang "permainan" dengan mendahulukan guru yang lebih tua (senior) dan memiliki masa kerja yang lama; Kedua, peluang praktik jual-beli ijazah demi memperoleh syarat kualifikasi akademik; Ketiga, dorongan terhadap guru untuk aktif mengikuti berbagai 
kegiatan ilmiah secara instan seperti seminar, lokakarya dan sebagainya memberi peluang untuk korupsi melalui suap dan sogok dan semacamnya. Keempat, penilaian proses pengajaran di sekolah berpeluang menimbulkan persekongkolan antara kepala sekolah, pengawas, dan guru itu sendiri untuk memberikan penilaian sangat tinggi padahal kenyataannya tidak demikian halnya. Kelima, partisipasi dalam kegiatan-kegiatan sosial di masyarakat dipastikan menuai masalah yaitu praktik atau tindak pemberian surat keterangan fiktif. Keenam, penilaian karya ilmiah melahirkan kecenderungan memperoleh karya dari orang lain dengan berbagai cara dan bentuk komersialisasi. Aneka modus tidak wajar tersebut di atas justru tidak melahirkan tenaga pengajar profesional dalam kategori yang sesungguhnya.

Untuk peningatan kualitas guru melalui program-program seperti workshop dan seminar, pemerintah harus menganggarkan pendanaan yang cukup besar. Dikuatirkan sertifikasi guru akan dicemari para koruptor dalam berbagai cara dan wujudnya. Dikuatirkan pula akan terjadi kecemburuan, pertikaian dan permusuhan antara guru yang telah memiliki sertifikasi dengan perolehan peningkatan gaji sebesar satu kali gaji pokok dengan guru yang belum sempat menikmati peningkatan kesejahteraan tersebut.

Alhasil, penerapan kebijakan sertifikasi guru tetap memerlukan pengkajian yang sangat cermat agar dapat terlaksana dengan murni dan berkeadilan tanpa dihinggapi praktik-praktik yang mencemarkan citra kependidikan. Apabila terjadi pencemaran citra kependidikan, terutama yang berkaitan dengan sertifikasi, maka kebijakan sertifikasi perlu dikaji secara lebih tuntas untuk menemukan titik terang menuju perubahan dan perbaikannya, atau bila mengalami jalan buntu maka dengan legowo bisa sampai pada keputusan bahwa kebijakan dan program sertifikasi ini dihapus sama sekali.

\section{Saran}

Demi mendapatkan sertifikasi guru harus lulus dalam uji sertifikasi yang dibuktikan dengan berbagai dokumen dalam berkas portofolio. Pengakuan atas pengalaman profesional guru dalam bentuk penilaian terhadap 10 komponen portofolio diperlihatkan dengan bukti fisik dari kegiatan pengajaran, pendidikan, pelatihan, serta jenis kegiatan sosial dan ilmiah lain yang pernah diikuti oleh guru terhadap kompetensi pedagogik, kepribadian, sosial, dan profesional.

Pelaksanaan terhadap tuntutan ini tidak mudah. Oleh sebab itu, disarankan kepada peserta uji sertifikasi atau pengumpul bukti-bukti fisik portofolio agar menyiapkan segala sesuatu secara cermat demi pelaksanaan uji sertifikasi melalui pemenuhan bukti fisik portofolio. Penilaian portofolio dan ujian diberikan oleh asesor. Jika peserta program kebijakan sertifikasi guru mengetahui adanya praktik kecurangan yang dilaksanakan oleh asesor atau pihak pelaksana lainnya, dihimbau para guru untuk menyampaikan hal itu kepada pihak terkait agar penerapan kebijakan sertifikasi guru berlangsung murni dan objektif.

\section{Pustaka Acuan}

Ahmad Rizali. 2008. Sertifikasi Guru - Evaluasi Persyaratan Portofolio. Ahmad Rizali kepada SP melalui surat elektroniknya, Jumat (14/3). http://www.suarapembaruan.com/News/2008/03/15/ Kesra/kes01.htm

Ahmadin. Mengurai Masalah Pelaksanaan Sertifikasi Guru. (http://www.fajar.co.id/ news.php?newsid=41205. 24 September 2007). Diakses pada tanggal 9 Juli 2009

Departemen Pendidikan Nasional (2006) Undang-undang Republik Indonesia Nomor 14, Tahun 2005 tentang Guru dan Dosen.

http://urip.wordpress.com/2006/10/31/ ada-apa-dengan-sertifikasi-guru/. Oktober, 2006. Diakses pada tanggal 24 Juli 2009

http://74.125.93.132/search?q=cache:ZEHYOVEFXEEJ: www.sertifikasiguru.org/uploads/File/ instrument/sertifikasiguru dalamjabatan 07.pdf+sertifikasi+gurum+portofolio\&cd $=11 \& \mathrm{hl}=\mathrm{id} \&$ ct $=$ clnk\&gl=id. Sertifikasi Guru Dalam Jabatan Tahun 2007 Diakses pada tanggal 24 Juli 2009 
http://www.suarapembaruan.com/News/2008/03/15/Kesra/kes01.htm Diakses pada tanggal 24 Juli 2009

http://www.antikorupsi.org/mod.php?mod=publisher\&op=viewarticle\&artid=10779 dari Jawa Pos, 4 Juli 2007. Diakses pada tanggal 8 Juli 2009

http://www.Suarakarya-Online.Com/News.Html?Id=183363. Diakses pada tanggal 24 Juli 2009

Silverius. 2000. Quo Vadis" Pendayagunaan Guru. Jurnal Pendidikan dan Kebudayaan. Juli 2000, Tahun Ke-6, No.024

Silverius, Suke. 2005. Sekolah Via Korupsi juncto Korupsi Via Sekolah - Tantangan Mutu Sumber Daya Manusia Indonesia. Isu-isu Pendidikan di Indonesia, Triwulan I, Januari-Maret, No. 5, Tahun ke2, Maret 2005

Silverius, Suke. 2003. "Guru, Pahlawan yang Dipahlawankan dalam Persebaran Guru Menurut Kebutuhan Sekolah". Selintas Pendidikan Indonesia di Awal Tahun 2003: Tujuh Isu Pendidikan.

Silverius, Suke. 2004. "Kongkalikong di Balik Buku Pelajaran". Isu-isu Pendidikan - Tujuh Isu Pendidikan Triwulan Keempat, Tahun I, No.4 . Jakarta, Desember 2004.

Silverius, Suke. 2007. Sertifikasi Guru - Memberdaya ataukah Memperdaya. Bunga Rampai - Isu-isu Pendidikan di Indonesia, Triwulan III, Juli-September, No. 15, Tahun ke-4, September 2007

Statistik Pendidikan 2007/2008 (Data dari PSP Balitbang Depdiknas. Belum diterbitkan).

Undang-Undang Republik Indonesia No.20 Tahun 2003 tentang Sistem Pendidikan Nasional Lembaran Negara Republik Indonesia No. 78, 2003. PENDIDIKAN. Sistem Pendidikan Nasional. Warga Negara. Masyarakat. Pemerintah. Pemerintah Daerah. (Penjelasan dalam Tambahan Lembaran Negara Republik Indonesia Nomor 4301) 